Godina IX | Broj 18 | Sveska 2/2021 | ISSN 2334-816X
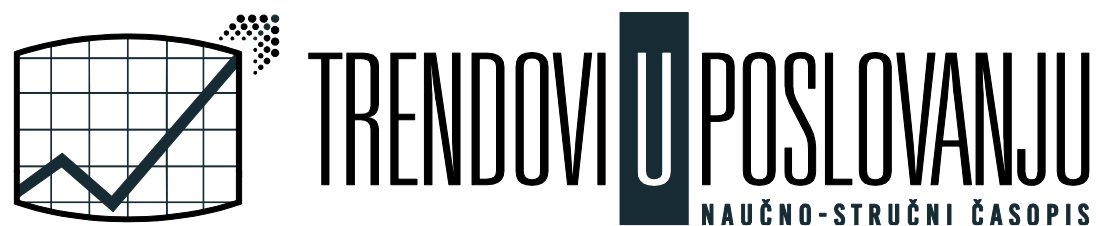

\title{
SOURCES AND MANIFESTATIONS OF FOREIGN LANGUAGE ANXIETY
}

\section{IZVORI JEZIČKE ANKSIOZNOSTI I NJENE MANIFESTACIJE}

Petrić Kruna| Visoka škola za poslovnu ekonomiju i preduzetništvo, Beograd, Srbija | kruna.petric@vspep.edu.rs

Milivojević Vesna | Visoka škola za poslovnu ekonomiju i preduzetništvo, Beograd, Srbija | vesna.milivojevic@vspep.edu.rs

Moretić Mićić Snežana| Visoka škola za poslovnu ekonomiju i preduzetništvo, Beograd, Srbija | snezana.moretic.micic@vspep.edu.rs

\begin{abstract}
Foreign language anxiety (FLA) is a type of anxiety related to all situations in which an individual is learning a foreign language. Are language teachers and learners in Serbia familiar with foreign language anxiety? If yes, to what degree? If no, why not? The problem needs to be recognized and acknowledged in order to be solved. FLA encompasses many a things, including personal traits, motivation, affect, age, the all important extroversion / introversion dichotomy, why it is happening and how, and what we can do about it, etc. In this paper, the goal is to explain the main sources and manifestations of FLA and, hopefully, raise a few questions for further discussion. If one wants to tackle the problem of FLA and try to help students overcome it, one must know where FLA comes from and how to recognize it in the classroom. This paper is not intended only for teachers, but also for students who have maybe thought about it but did not know it has a name foreign language anxiety - and that there are ways to mitigate it.
\end{abstract}

\section{Sažetak}

Jezička anksioznost (Foreign Language Anxiety - FLA) je vrsta anksioznosti koja se odnosi na sve situacije u kojima pojedinac uči strani jezik. Da li su nastavnici jezika i učenici u Srbiji upoznati sa anksioznošću stranog jezika? Ako da, u kom stepenu? Ako ne, zašto ne? Pre samog rešavanja problema, sa njim se naravno treba upoznati. FLA obuhvata mnogo stvari, uključujući lične osobine, motivaciju, emocionalnu inteligenciju, godine, dihotomiju ekstroverzija / introverzija, zašto se dešava i kako, i šta možemo da uradimo povodom toga, itd. $U$ ovom radu, cilj je objasniti glavne izvore i načine manifestovanja jezičke anskioznosti postaviti par pitanja za dalju diskusiju. Ukoliko želimo da se bavimo problemom FLA i pokušamo da pomognemo učenicima da ga prevaziđu, moramo znati odakle FLA dolazi i kako je prepoznati u učionici. Ovaj rad nije namenjen samo nastavnicima, već i učenicima koji su možda razmišljali o tome, ali nisu znali da ima ime - jezička anksioznost - i da postoje načini da je ublaže.

Key words: foreign language anxiety, FLA sources, FLA manifestations

Ključne reči: jezička anksioznost, FLA izvori, FLA manifestacije

JEL klasifikacija:Z13

DOI:10.5937/trendpos2102052P

UDK: 37.091.3::81'243

159.947-057.87

COBISS.SR-ID 52308745 


\section{Introduction}

Foreign language anxiety (FLA), or anxiety related to all situations in which an individual is learning or acquiring a foreign language, has been in the focus of many linguistic researches related to the significance and influence of affect on second language acquisition. It has been proven on numerous occasions how harming FLA is for academic and general language achievement, unconstrained cognitive processes, communication in a foreign language, etc. [1][[2][3]. Are language teachers and learners in Serbia familiar with foreign language anxiety? If yes, to what degree? If no, why not? We need to recognize and acknowledge the problem in order to solve it. Anxious learners need to know they are not alone and that there are teachers who are very much aware of the troubles they are having.

In this paper, the goal is to explain the main sources and manifestations of FLA and, hopefully, raise a few questions for further discussion. The idea to write about this came from the authors' personal war against FLA, first as students and now as teachers. In the authors' modest opinion FLA is one of the strongest opponents of a successful foreign language acquisition and the problem needs to be addressed on a larger scale.

\section{Defining FLA}

Anxiety, in a variety of its forms, has existed for as long as human beings have existed. However, its significance and influence was first noted and emphasized by Freud in the first half of the $19^{\text {th }}$ century. He perceived anxiety as something that we feel - a distinct uncomfortable emotional state which includes experiential, physiological and behavioural segments [4]. Cambridge Advanced Leaner's Dictionary defines anxiety as "an uncomfortable feeling of nervousness or worry about something that is happening or might happen in the future." Interesting is the word "might" which makes anxiety different than fear. Fear exists when there is an immediate threat, when we fear for our life and safety and anxiety occurs when individuals perceive certain situations as stress-provoking. Anxiety has well-defined common characteristics observed and noted via clinical research, such as sweaty palms, palpitations, forgetfulness, difficulties concentrating, [5] and we all experience it in this way or another, more or less frequently. An important difference is how well we learn to cope with it.

There are three types of anxiety: trait, state and situation-specific. Spielberger differentiates between two types of anxieties and those would be trait and state. Trait anxiety is a rather constant and stable quality in an individual appearing throughout a longer period of time and is not related to a particular situation. It is seen as a personality trait. State anxiety is a more narrowed term and it occurs when there is a stressful situation or, as psychologists would say, a stressor or a stimulus. Spielberger explains that "anxiety states are characterized by subjective feelings of tension, apprehension, nervousness, and worry, and by activation or arousal of the autonomic nervous system" [6]. MacIntyre and Gardner, for the purposes of exploring the vastness we call language, discuss one more - situation-specific anxiety. This is where we will find foreign language anxiety (FLA). The term is somewhat self-explanatory and concerns a specific situation in which an individual repeatedly experiences stress. When it comes to the topic of this thesis, situation-specific anxiety relates to all situations in which an individual is learning or acquiring a foreign language [2]. It is relevant to mention that FLA correlates only weakly with general trait anxiety and that it is observed as a distinct variable in the process of acquiring a foreign language [5]. 


\section{Source and manifestations of Foreign language anxiety}

The question does not have to be how something is happening, what caused it or results from it. The question of why something is happening will always crawl out of its dark holes of curiosity. Yes, FLA can be the cause or effect, depending on whose scientific grounds we stand, but why we "let" it happen, what the mechanisms behind it are, can we control it or not, and how we recognize them are questions begging to be answered.

Young differentiates between six sources of anxiety:

1) "personal and interpersonal anxieties;

2) learner beliefs about language learning;

3) instructor beliefs about language teaching;

4) instructor-learner interactions;

5) classroom procedures; and

6) language testing." [7]

FLA can be manifested in three ways: 1) communication apprehension; 2) test anxiety; and 3) fear of negative evaluation [5]. In the framework of these tree types, we shall further explain the connection between the sources of FLA and its manifestations.

Let us elaborate the 6 sources in order of appearance. Most commonly discussed sources are personal and interpersonal anxieties since everything begins with the protagonist, i.e. the learner. The word person comes from the Latin word persona meaning a mask, so when we put our masks down in the FL classroom, what are we, the anxious ones, left with? Low selfesteem ("I cannot possibly learn this, I am not smart enough"), high expectations ("I need to be better than others, but I simply cannot be."), envy ("I wish I was as smart and talented for languages as Tom, Dick and Harry.") jealousy ("She must have been to England, otherwise she would not be speaking English so well, she has got advantage over me."). These are just some of the possible thoughts going through the burdened minds of language learners and messing with their concentration, memory, and ability to utter meaningful and complete sentences. Is it irreparable and without its benefits? Most certainly not.

Learner's beliefs about language learning are rather important because they form our expectations of ourselves and of our performance. In her study on the beliefs on language learning Elaine Horwitz came to certain conclusions. Namely, students worry about the correctness of their sentences, they believe having a great accent is of vital importance and that other students are more talented for languages than they are. They also believe they can learn languages in a fairly short period of time and speak them fluently and that to learn English is to translate from it [8]. We can see how these beliefs can have a negative impact since they provide a false and rather negative image of language learning. For example, if we start learning English in September and if by the end of two-year period we have given ourselves we are not able to retell a novel that we like, we will feel frustrated. Hence, when beliefs, expectations and reality do not go hand in hand, a massive problem occurs and our self-image weakens thus reducing our cognitive abilities.

Instructor's beliefs about language teaching can be more of a problem than we give it credit to. We have all had that one teacher whose classes we did not like to attend not because we did not like the subject, but because we did not like the person standing in front us. In FL classrooms, teachers are our knowledge gurus, we rely on them to help us find knowledge, so when our teachers are unpleasant, unrealistic in their expectations, non-pedagogical in their attitude towards students, a problem occurs. If teachers use their classrooms to master their strictness and faux authority, and not warmth, democracy and above everything else knowledge, then students will use their classroom to unwillingly feed their fears and anxieties 
related to learning. Teachers "who believe that the teacher should be doing most of the talking and teaching, and who think their role is more like a drill sergeant's role than a facilitator's may be contributing to learner language anxiety" [7].

Instructor-learner interaction is something to be dealt with very carefully. On the one hand, we have cases of teachers being our friends instead of our friendly teachers. In that case, the chances of having anxious students are slim, but the chance of having undisciplined class is very likely, especially if teaching younger students. On the other hand, we have teachers who demand too much of their students, who correct every mistake they make, who tend to reprimand harshly when a minor mistake is made, and in that way nurture anxiety and self-consciousness in their students. Error correcting is necessary, and students need that. "The issue for the student, then, is not necessarily error correction but the manner of error correction - when, how often, and, most importantly, how errors are corrected" [7].

"Any volunteers to complete this exercise in front of the class?" - The teacher asks and no hand is raised. Class procedures can be designed to nurture anxious and shy minds of our students in an effective way or they can be designed in a way that feeds foreign language anxiety. Research concerning class procedures and their impact on FLA tells us that one of the most stress-provoking activities is speaking in front of the class. In a research on speaking anxiety (SA), out of 240 students aged 17 to 24, more than a half, 125 students to be precise, reported moderate or high level of SA [9]. In another research carried out by Young which included 244 Spanish students, top three answers reported to provoke the highest level of anxiety in students were: 1 ) to make an oral presentation or skit in front of the class; 2) speak in front of the class; 3 ) role play a situation spontaneously in front of the class. Students reported they do not feel either anxious or relaxed when, e.g. they have to speak in pairs, in teams or alone with their teacher. Young concluded that what all high-stress activities have in common is a high exposure student requirement, i.e. students feel most afraid and ashamed of speaking in front of others [10]. Since practice is a vital factor in FL acquisition, teachers need to gradually and patiently expose their students to more speaking activities in order to try and minimize their negative effect.

Language testing anxiety begins long before the actual test which is only the climax of our bottled-up stress. The moment we, students, hear we will have an important test in, for example, two-week time, a process begins. "Do I have all the necessary literature and notes, do I have enough time, what if I postponed my exam for the next exam period?" - These are just some of the questions that pop up in our brains long before the exam. Then we start studying and realize how much we are lagging behind, how many notes we have not written down, how many important pieces of information our lazy minds have forgotten, how short two-week period is, etc. Then we try to calm down by telling ourselves how that is just a test, how we actually are prepared for it, how there is always another chance, how the lowest grade is, after all, enough. Often have the teachers seen sweaty palms, shaky hands, blushed cheeks and wandering eyes in their students. Our test begins and we realize the test is not the problem, it is what it is, we can try and do it the best we can or we can hand in our blank copy of the test, it's up to us. The problem is what happens next. "What if I disappoint my teacher, myself and others? I've had plenty of time, I guess I am simply not smart enough if I cannot do this." - 1:0 in favour of anxiety. Another problem can be the inconsistency in the class material taught by the teacher and the material given at the test, so "in language testing, the greater the degree of student evaluation and the more unfamiliar and ambiguous the test tasks and formats, the more the learner anxiety produced" [7].

When it comes to students' manifestation of anxiety, it comes in various forms and degrees of intensity. Sometimes it can be easily noticed and sometimes teachers need to look for subtle cues. As students, we tend to think we are good at hiding our fears and we often switch our defence mechanisms on and try to hide our anxiety with sense of humour and charm, or with 
rudeness and deflection. As teachers, observant and good-at-noticing-details teachers, we tend to see this and ascribe it to students' (lack of) ability to cope with pressures they are experiencing. According to Leary, we can recognize anxious students who have not yet learned to hide or mask their anxieties, when we see them "squirm in their seats, fidget, play with their hair, clothes, or other manipulable objects, stutter and stammer as they talk, and generally appear jittery and nervous" [11].

Students manifest anxiety mainly when speaking and listening to their FL of choice. It often happens that students know a certain rule, but freeze up when having to speak in front of others or when found in a situation in which they are being evaluated (be that oral or written test/exam). Some students have problems distinguishing sounds and they often feel confused when listening to their teachers, audio tapes or peers. Other possible manifestations would be skipping class, sitting quietly in the far back seat in the classroom, hopping in front of the classroom trying to get the courage necessary for taking the exam, trying to dodge every opportunity to speak in the foreign language [5].

It can be concluded that FLA is like a labyrinth full of dark secret passages leading nowhere, but teachers can help their students find the right path and maybe, along the way, learn a few metaphors.

\section{Conclusion}

It cannot be emphasized more how important it is for all of us to acknowledge the existence and presence of foreign language anxiety. It started with Horwitz, Horwitz and Cope in 1986 and has been talked about and researched ever since. But has it been talked about enough? If asked, would all teachers be familiar with the term? Would they have an opinion about it and have some advice to give or questions in need of answers?

As mentioned at the very beginning of this paper, the essential idea behind this paper was to show how anxiety is in our classrooms, sitting at our desks, writing on our blackboards, meddling with our cognition and how it is very much present and making us problems. If just one language teacher reads this paper, acknowledges the existence and presence of FLA, recognizes an anxious learner and helps him or her to understand how they are not alone, how anxiety is not something unsolvable and how each and every one of us is in charge, then the author of this paper will consider it a success. 


\section{References}

[1] Horwitz, E. K. Preliminary evidence for the reliability and validity of a foreign language anxiety scale, TESOL Quarterly, 1986, pp. 559-562.

[2] MacIntyre, P., Charos C.Personality, Attitudes, and Affect as Predictors of Second Language Communication, Journal of Language and Social Psychology,1996,15 (no. 1): pp. 3-2.

[3] MacIntyre, P. D., Gardner, R. C. The Subtle Effects of Language Anxiety on Cognitive Processing in the Second Language, A Journal of Research in Language Studies,1994, 44 (no. 2): pp. 283-305

[4] Freud, S.The problem of anxiety. New York: W.W. Norton,1936

[5] Horwitz, E. K., Horwitz M.B., Cope J. Foreign Language Classroom Anxiety, The Modern Language Journal,1986, (no. 2): pp. 125-132.

[6] Spielberger, C. D. et al. State-Trait Anxiety Inventory for Adults, Sampler Set, Manual, Instrument and Scoring Guide.1983, California: Mind Garden, Inc.

[7] Young, D. J. Creating a Low-Anxiety Classroom Environment: What Does Language Anxiety Research Suggest?, The Modern Language Journal,1991, (no. 4): pp. 426-439.

[8] Horwitz, E. K.The Beliefs about Language Learning on Beginning University Foreign Language Students, The Modern Language Journal,1988, 72(iii): pp. 283-294

[9] Tianjian, W. Speaking Anxiety: More of a Function of Personality than Language Achievement, Chinese Journal of Applied Linguistics ,2010,33 (no. 5): pp. 95-109.

[10] Young, D. J. An Investigation of Students' Perspectives on Anxiety and Speaking, Foreign Language Annals, 1990, 23 (no. 6): 539-553.

[11] Leary, M. R. Social Anxiety, Review of Personality and Social Psychology 3.1992, Ed. Ladd Wheeler. Beverly Hills: Sage 